University of Nebraska - Lincoln

DigitalCommons@University of Nebraska - Lincoln

2006

\title{
Market Disintermediation and Producer Value Capture: The Case of Fair Trade Coffee in Nicaragua, Peru and Guatemala
}

\author{
Eric J. Arnould \\ University of Arizona \\ Alejandro Plastina \\ University of Nebraska \\ Dwayne Ball \\ University of Nebraska-Lincoln, dball1@unl.edu
}

Follow this and additional works at: https://digitalcommons.unl.edu/marketingfacpub

Part of the Marketing Commons

Arnould, Eric J.; Plastina, Alejandro; and Ball, Dwayne, "Market Disintermediation and Producer Value Capture: The Case of Fair Trade Coffee in Nicaragua, Peru and Guatemala" (2006). Marketing Department Faculty Publications. 11.

https://digitalcommons.unl.edu/marketingfacpub/11

This Article is brought to you for free and open access by the Marketing Department (CBA) at DigitalCommons@University of Nebraska - Lincoln. It has been accepted for inclusion in Marketing Department Faculty Publications by an authorized administrator of DigitalCommons@University of Nebraska - Lincoln. 


\section{Market Disintermediation and Producer Value Capture: The Case of Fair Trade Coffee in Nicaragua, Peru and Guatemala}

Eric J. Arnould, University of Arizona, Alejandro Plastina, University of Nebraska, Dwayne Ball, University of Nebraska

\footnotetext{
Paper prepared for presentation at the Conference, "Product and Market Development for Subsistence Marketplaces: Consumption and Entrepreneurship Beyond Literacy and Resource Barriers," 2-4 August 2006, University of Illinois at Chicago (http://www.uic.edu/depts/oee/submarkets/program.htm)
}

July 2006 


\begin{abstract}
Does participation in Fair Trade coffee marketing deliver added value to small-scale producers in developing countries? Is Fair Trade fair to producers as promised? The present study adopts a survey methodology designed to measure a combination of socio-economic impact indicators as well as measures particular to the Fair Trade coffee growing and marketing experience. We surveyed over 1200 small-scale coffee producers in Nicaragua, Peru, and Guatemala, of which about two-thirds participate in coffee marketing schemes sponsored by Transfair, USA. The study reports selected results related to production, marketing, material quality of life, education, health, and general wellbeing. Results show that producers participating in Transfair-supported Fair Trade cooperatives are indeed capturing more value than non-participants. This benefit transfer translates into modest but measurable improvements in quality of life, health, education, material comforts, social participation, technical and social assistance, and even sustainable agricultural practices. Consumers can have confidence that the Fair Trade scheme works. Retailers may be assured that by selling Fair Trade coffee they can defend the position that they are participating in a social change campaign.
\end{abstract}




\section{Market Disintermediation and Producer Value Capture: The Case of Fair Trade Coffee in Nicaragua, Peru and Guatemala}

Does participation in Fair Trade coffee marketing deliver added value to smallscale producers in developing countries? Is Fair Trade fair to producers as promised (Mashland and de Vaal 2002)? The answer to this question is critical to at least two stakeholder groups. The answer is meaningful for small-scale agricultural producers whose livelihoods and well being are affected by their adherence to the certification norms that make them eligible for participation in Fair Trade's cooperative pricing schemes. The answer is also crucial for the continued credibility of the value proposition that differentiates Fair Trade products in the consumer marketplace of developed countries. And thus it is of interest to consumers of fairly traded products who are fuelling dramatic growth in this category and to the retailers who offer them (Grolleau and BenAbid 2001; SCAA 2004; The Economist 2006).

Transfair USA was awarded a grant by the Tinker Foundation in the year 2003 to study the impact of Fair Trade (FT hereafter) practices on coffee producers with small productive units in the Latin American region. The Agribusiness program at the University of Nebraska initiated the study under agreement with Transfair USA. The study was implemented in 2004-2005. Three countries with significant Fair Trade marketing to through Transfair, USA were selected for the study: Nicaragua, Peru and Guatemala. The study attempts to document in each country significant differences between FT and non-FT coffee producers presently engaged in coffee production as a result of differences in producer prices of coffee paid to FT and non-FT producers, regarding selected aspects of coffee production, income, investment and savings, housing quality, opportunities for social and economic improvement, educational attainment, health status and quality of life. This paper reports selected results related 
primarily to income, housing quality, opportunities for social and economic improvement, education, and subjective quality of life.

Before turning to a discussion of method and results, we first present a brief introduction to the Fair Trade business model. Fair Trade comprises a number of elements. First, it is a sourcing strategy primarily for agricultural commodities produced in tropical or sub-tropical developing countries including coffee, chocolate, tea, bananas, sugar, and others. The sourcing is undertaken by a loose international confederation of non-profit organizations, one of which Transfair, USA commissioned this report.

Second, the core of the sourcing strategy is market disintermediation. In other words, Fair Trade organizations seek to reduce the layers of middlemen between producers in the developing world and consumers in the developed world by handling a number of logistics and product certification functions.

Third, the reason for undertaking this strategy is to move value shares up the market channel so that poor producers in developing countries receive a greater share of the purchase price consumers pay for the products they produce (Johnston 2002). Setting floor producer prices at a fixed percentage above average global market prices achieves this. If prices rise well above average norms, producers should reap a windfall, if they fall below them, they are protected from volatile price downturns. As a result, Fair Trade, USA claims an additional US\$ 67 million has been transferred to participating farmers since 1999 through their marketing channels.

Fourth, Fair Trade often represents a social change mechanism because pricing schemes are implemented through local cooperatives that are supposed to deliver technical and social assistance to members in areas ranging from sustainable agriculture practices to women's programs (Crowell 1997; Murray, Raynolds and Taylor 2003; Strong 1997). 
Downstream, Fair Trade may be thought of as a meaningful way to differentiate products at the retail level, and thus adding Fairly Traded products to the merchandise mix may be thought of as a retail positioning strategy (Littrell and Nicholls 2002; Wellford and Young 2003). Some 100 million pounds of Fair Trade coffee have been certified since 1999, and Fair Trade coffee is the fastest growing segment of the US coffee market. Fair Trade coffee sales have been growing at a rate of $67 \%$ a year as compared to $12 \%$ growth for organic coffee according to the Specialty Coffee Association (2004). Transfair reports a $60 \%$ retail location growth from ' 03 to ' 04 , and observes that fairly traded coffee products can now be found in over 35,000 retail locations in the US. While awareness of Fair Trade coffee is relatively low among US consumers (15\% versus $52 \%$ for organic coffee), awareness translates at a higher rate into sales than organic ( $50 \%$ vs. $25 \%$; NCAUSA 2005). In the UK, Fair Trade is even more developed than in the US in terms of product diversity. Over 1500 FT products can be purchased in the UK now including clothing (Dickson and Littrell. 1998) and sporting goods and scores of towns and villages subscribe to a fair trading certification scheme (for details see www.fairtrade.org.uk).

Finally, Fair Trade may be considered a self-taxing scheme for concerned consumers who basically agree to pay higher prices in return for the promise that producers in developing countries will benefit directly (Bird and Hughes 1997; Young and Welford 2002). In other words, this is a way for consumers in developed countries to finance social assistance to producers in developing countries.

\section{Method}

We chose a survey methodology designed to measure a combination of socioeconomic indicators as well as measures particular to the FT coffee growing and marketing experience for this study. This choice was dictated by our belief that key 
audiences (e.g. international funding agencies; managers; management academics) more easily accept the generalizability of the results of this type of study than those produced through ethnographic techniques, case study methodologies, and journalistic reports that predominate in the existing literature on the impact of Fair Trade (MacDonald 2006; Nicholls and Opal 2005; Parrish, Luzadis and Bentley 2005; Raynolds, Murray and Taylor 2004; Ronchi 2002).

The population under study includes coffee producers and their families whose productive units are small and are thus FT certifiable (1-3 hectares of coffee production per adult, over the age of 18 living in the household), who are currently producing coffee in traditional coffee areas under homogeneous environmental and social conditions. The two types of farmers surveyed include Fair Trade certified farmers, who meet the additional criteria of at least three years of participation in Fair Trade coops and affiliation with cooperatives with consistent sales of at least $30 \%$ of their production to Fair Trade cooperative buyers, and non Fair Trade independent farmers, who may or may not be affiliated with other cooperative entities. Due to a misunderstanding in the fieldwork in Peru, field workers sought to identify coops with a maximum (instead of a minimum) of $30 \%$ of their sales through the FT system. We choose to report the analysis of the Peruvian data because we still find some relevant differences among FT members and non-members.

We drew stratified random cluster samples from the specified target populations in the three countries. On the assumption that cooperative size might affect the impact of FT participations, coops were stratified by size of the membership, and comparative communities were selected through adjacency sampling. In the first stage, cooperatives were selected by simple random sampling from the strata they were classified into. In the second stage, coffee producers were selected by simple random sampling from within each cooperative and using as the sampling frame a recent list of all producers in 
each cooperative (cooperative census data). Farmers from adjacent communities were selected by random sampling from the area adjacent to the cooperative under analysis subject to strictures of local geography and infrastructure development (no sampling frame was available in Nicaragua or Guatemala). While we cannot claim sample selection matches ideals outlined in methodological textbooks, we feel certain that standard sources of systematic error have been minimized if not eliminated. All in all we questioned about 1200 household heads in the three countries two-thirds of whom were FT participants.

Table 1. Sample size in each country

\begin{tabular}{|c|c|c|c|c|c|c|}
\hline \multirow[b]{2}{*}{ Country } & \multicolumn{4}{|c|}{ Fair Trade } & \multirow[b]{2}{*}{$\begin{array}{c}\text { Non- } \\
\text { Members }\end{array}$} & \multirow[b]{2}{*}{ Total } \\
\hline & $\begin{array}{l}\text { Small } \\
\text { Coops }\end{array}$ & $\begin{array}{l}\text { Medium } \\
\text { Coops }\end{array}$ & $\begin{array}{l}\text { Large } \\
\text { Coops }\end{array}$ & FT Total & & \\
\hline Peru & 30 & 117 & 130 & 277 & 125 & 402 \\
\hline Nicaragua & 57 & 70 & 212 & 339 & 123 & 462 \\
\hline Guatemala & 64 & 85 & 116 & 265 & 140 & 405 \\
\hline Total & 151 & 272 & 458 & 881 & 388 & 1269 \\
\hline
\end{tabular}

The questionnaire was designed in Spanish, and except for a few questions that were modified to accommodate country specificities (i.e., local currency, units of land area, schooling characteristics, sustainable agricultural practices), exactly the same set of questions was implemented in the three locations. The questionnaire consisted of four sections. The first section focused on the production and marketing processes. The second section focused on the local living conditions and a self-assessment of producers' wellbeing. The third section focused on household members' education. The last section inquired about the health condition of family members and their access to professional health care.

\section{Findings}


We report just a few highlights from the data here. We have not pooled the data across countries because pooling the data and running new analyses (considering each location as a random variable) does not change the overall results. Even if it might add some robustness to the conclusions (in the sense that they can be generalized to all Fair Trade producers were location indeed a random variable), it will not really change the overall conclusions drawn from the country level data.

\section{Comparability}

Only in Guatemala as shown in Table 2 was there a significant difference between FT and non-member household size. FT households supported one more member on average than non-member households.

Table 2. Mean Number of People per Household

\begin{tabular}{|c|c|c|c|}
\hline Country & FT Members & Non-Members & $\begin{array}{c}\text { Equal Mean } \\
\text { t-test }\end{array}$ \\
\hline Peru & 4.14 & 4.20 & 0.292 \\
\hline Nicaragua & 5.54 & 5.65 & 0.481 \\
\hline Guatemala & 6.10 & 5.37 & $23.269^{*}$ \\
\hline${ }^{*} p<.05$
\end{tabular}

In Peru, the mean age of the household head among non-member producers is about 3.8 years greater than the corresponding age among FT members (Table 3 ). In Nicaragua, there is no significant difference in this demographic variable among members and non-members. Finally, the mean age of the household head is 3.6 years smaller for non-member producers than for FT members in Guatemala. However, the mean differences are small and all household heads may be considered of middle age.

Table 3. Mean Age of the Household Head

\begin{tabular}{|c|c|c|c|}
\hline Country & FT Members & Non-Members & $\begin{array}{c}\text { Equal } \\
\text { Mean } \\
\text { t-test }\end{array}$ \\
\hline Peru & 51.94 & 55.73 & $2.686^{*}$ \\
\hline
\end{tabular}




\begin{tabular}{|c|c|c|c|} 
Nicaragua & 44.29 & 43.78 & 0.349 \\
\hline Guatemala & 47.12 & 43.51 & $18.98^{*}$ \\
\hline
\end{tabular}

${ }^{*} p<.05$

Overall, demographic indicators suggest we were comparing similar units between the

FT and non-FT groups. That is, we were comparing comparable households that differed primarily in membership status.

Results from all three countries indicate significant differences in indicators between Fair Trade and non-Fair Trade farmers in the predicted direction. In other words, in each of the domains of impact, significant positive differences for Fair Trade participating farmers have been detected.

\section{Production and Marketing}

FT households generally plant slightly larger area than non-member households as shown in Table 4.

Table 4. Mean Coffee Area (hectares $\cong 2.26$ acres)

\begin{tabular}{|l|l|l|l|}
\hline & FT Members & Non-members & Significance test \\
\hline Peru & 2.36 & 1.44 & $\mathrm{t}=-5.621 ; \mathrm{df}=399 \mathrm{p}=.000$ \\
\hline Nicaragua & 2.68 & 1.3 & $\begin{array}{l}\text { ANOVA Sum of squares }= \\
24.853 ; \mathrm{df}=1 ; \text { Mean Square }= \\
\end{array}$ \\
& & & $\begin{array}{l}24.853 \mathrm{~F}=9.946 ; \mathrm{p}=.002^{*} \\
\mathrm{t}=-12.115, \mathrm{df}=6438.71, \mathrm{p}= \\
.000\end{array}$ \\
\hline Guatemala & 1.11 & 1.03 & \\
\hline
\end{tabular}

${ }^{*}$ Non-members and members of the three sizes of coops were compared.

FT households generally report selling more coffee and receiving higher prices and incomes than non-FT households, as suggested in Tables 5 and 6 , although small coop member's incomes lagged in Nicaragua (see Figure 1). In Peru FT participants sold more and received higher prices for coffee than non-participants.

Table 5. Coffee Traded Volumes, Quintals (one quintal $\cong 50 \mathrm{~kg}$ )

\begin{tabular}{|l|l|l|l|}
\hline & FT Members & Non-members & Significance test \\
\hline Peru & 26.7 & 17.6 & $\mathrm{t}=-7.762, \mathrm{df} .=396, \rho<.000 \mathrm{I} ;$ \\
\hline
\end{tabular}




\begin{tabular}{|l|l|l|l|}
\hline Nicaragua & & & with equal variances assumed \\
& $20-30$ & $10-20$ & $\begin{array}{l}\text { ANOVA Sum of squares }= \\
177.443 ; \mathrm{df}=1 ; \text { Mean } \\
\text { square=177.443; } \mathrm{F}=22.611 ; \\
\mathrm{p}=.000^{*}\end{array}$ \\
\hline Guatemala & 25.7 & 23.5 & $\begin{array}{l}\mathrm{t}=-9.819, \mathrm{df}=8389.48, \mathrm{p}= \\
.000\end{array}$ \\
\hline
\end{tabular}

${ }^{*}$ Non-members and members of the three sizes of coops were compared.

Table 6. Mean Price for APO per Quintal 2004 (in local currency)

\begin{tabular}{|c|c|c|c|} 
Country & FT Members & Non-Members & $\begin{array}{c}\text { Equal Mean } \\
\text { t-test }\end{array}$ \\
\hline Peru & 180.50 & 143.50 & $13.02^{*}$ \\
\hline Nicaragua & 47.20 & 25.40 & $17.7^{*}$ \\
\hline Guatemala & 737.00 & 619.00 & $65.14^{*}$ \\
\hline
\end{tabular}
${ }^{*} p<.05$

Figure 1 Price Per Quintal: Nicaragua

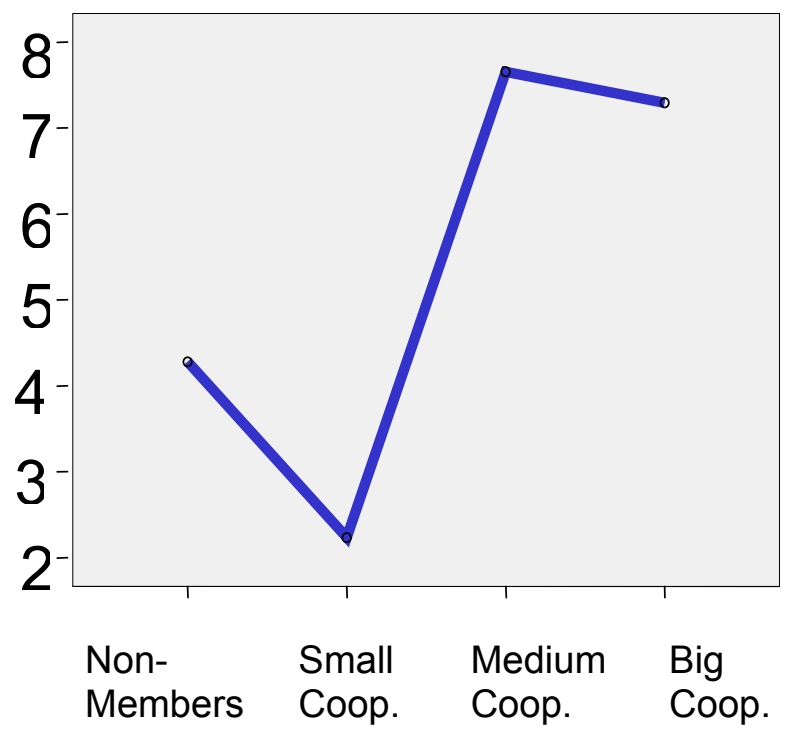

Interestingly, in Nicaragua, analysis including only women from FT coops shows that women claim that they have received significantly higher prices than men for two types of coffee, and women achieved price parity elsewhere. In Guatemala, FT members sold more coffee, and as shown in Table 6, earned more than non-members. However, between 2005 and 2004, non-members claim to have experienced a greater 
increase in their coffee incomes than FT coop members. This suggests market prices may be aligning with Fair Trade prices in this country. In Guatemala, data suggests a female FT coop member is more likely to benefit from better coffee prices than a male non-member although she may not receive prices equivalent to male FT coop members as shown in Figure 2 below. Gender discrimination in prices is forbidden in Transfair rules, and we have no explanation for these gender-differentiated results.

\section{Figure 2}

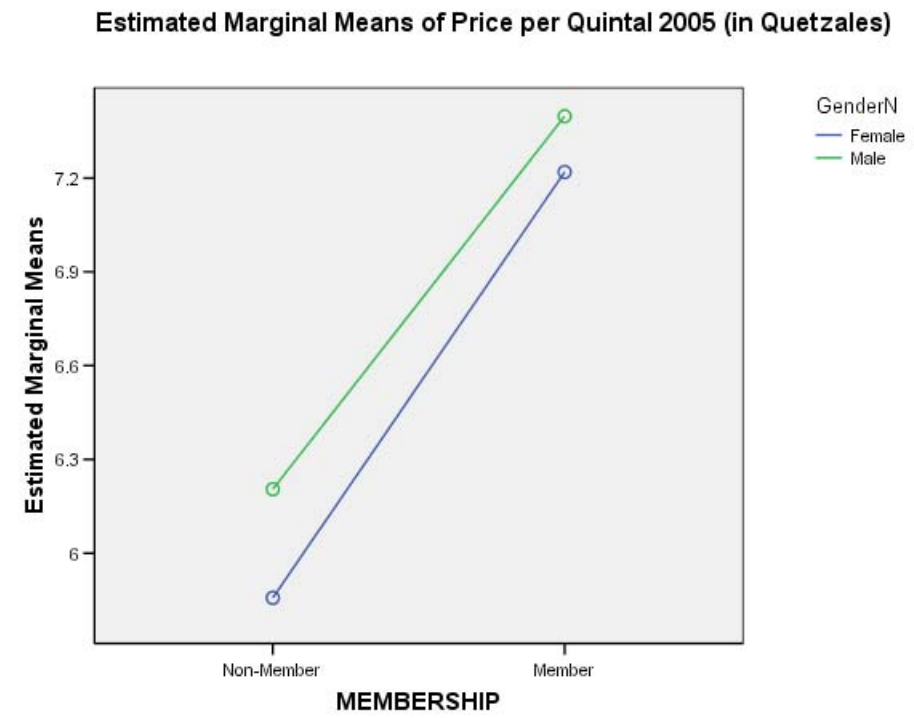

In terms of agriculturally sustainable practices in Nicaragua, a higher, statistically significant proportion of FT members claim to have increased shade grown coffee production over the last three years than non-FT members. This pattern was not repeated elsewhere. Across groups in Guatemala, more than $50 \%$ claim to have increased the share of shade-grown coffee they grow during the past three years. In Peru about $40 \%$ of both groups have increased their production of shade grown coffee and none has increased production of non-shade grown coffee. In Guatemala, organic fertilizer use and sustainable practices employing crop residue were reported to be higher among Guatemalan FT participants than non-participants as shown in table 7. FT 
members in Guatemala also reported use of a broader variety of agricultural inputs than did non-FT coop members. We did not measure these practices in the other countries.

Table 7. Use of Sustainable Agricultural Practices in Guatemala

\begin{tabular}{|c|c|c|c|}
\hline & $\begin{array}{l}\text { FT Coop } \\
\text { Members }\end{array}$ & Non-Members & Significance Tests \\
\hline \multicolumn{4}{|l|}{ Fertilizer Use } \\
\hline No use & 15.5 & 41.4 & $K-W X^{2}=122.603 ; d f=1 ; p=.000$ \\
\hline Synthetic Fertilizer & .9 & 12.9 & \\
\hline Organic Fertilizer & 79.1 & 31.4 & \\
\hline Mixture of Fertilizers & 4.6 & 13.6 & \\
\hline Others & 0 & .7 & \\
\hline Total & 100.0 & 100.0 & \\
\hline Crop Residue Use & & & $K-W X^{2}=41.351 ; d f=1 ; p=.000$ \\
\hline None & 18.6 & 32.9 & \\
\hline Natural Treatment & 14.4 & 5.0 & \\
\hline Use in the plot & 66.8 & 62.1 & \\
\hline Chemical Treatment & 2 & & \\
\hline Total & 100.00 & 100.00 & \\
\hline Fungicide Use & & & $K-W X^{2}=430.110 ; d f=1 ; p=.000$ \\
\hline No & 94.0 & 98.6 & \\
\hline Yes & 5.6 & 1.4 & \\
\hline Not sure & .3 & 0 & \\
\hline & 100.0 & 100.0 & \\
\hline $\begin{array}{l}\text { Increase in Shade } \\
\text { Grown Coffee }\end{array}$ & & & $K-W X^{2}=6.668 ; d f=1 ; p=.010$ \\
\hline No & 40.26 & 43.39 & \\
\hline Yes & 52.5 & 50 & \\
\hline Not sure/Don't know & 7.24 & 6.61 & \\
\hline
\end{tabular}

\section{Material Quality of Life}

Household level impacts in terms of material standards of living are variable across countries and across groups. In Nicaragua everyone's home has a dirt floor; in Guatemala, most FT participants' homes have cement or tile floors in contrast to the dirt floors of non-members. In Nicaragua, a slightly higher proportion of Fair Trade coop 
members compared to non-members have pure drinking water directly available. In Peru, the proportion of non-participants whose drinking water comes from an unprotected source is almost three times higher than the corresponding proportion of FT coop participants. Access to water through a potable communal water source is by far the most frequent source of water reported among FT coop members in Guatemala. In Peru, twice as many participants have added a room to their house in the past three years as non-participants, although only a quarter of respondents have done so. Guatemalan FT members are also more likely to have added a room than non-members. This indicator differs from the Nicaraguan case where no such difference was reported. In Guatemala, FT households generally have access to electricity as is not true elsewhere, and not true of non-participating households in Guatemala (74\% vs. $43 \%)$. In Nicaragua as in Guatemala, while few have purchased new TVs in the last three years, more FT members than non-members have done so.

\section{Literacy and Education}

Table 8 shows findings for literacy in Nicaragua and Peru. In Nicaragua, a higher proportion of FT coop members enjoy basic literacy than in the non-members group but we found no significant differences in school attendance of children across all age categories or by gender between the two groups. In Peru, for all categories of educational attainment except university attendance, FT participation is not a significant predicator of attainment. FT coop member households have higher reported levels of educational attainment and aspiration than non-member households in Guatemala; indeed their attainment is higher than in other countries as shown in Table 9. 
Table 8. Level of Literacy of Family Members (\%)

\begin{tabular}{|c|c|c|c|c|}
\hline & \multicolumn{2}{|c|}{ Peru } & \multicolumn{2}{|c|}{ Nicaragua } \\
\hline & $\begin{array}{l}\text { FT } \\
\text { Members }\end{array}$ & $\begin{array}{l}\text { Non } \\
\text { Members }\end{array}$ & $\begin{array}{l}\text { FT } \\
\text { Members }\end{array}$ & $\begin{array}{l}\text { Non } \\
\text { Members }\end{array}$ \\
\hline Illiterate & 7.10 & 8.60 & 9.10 & 8.10 \\
\hline Incomplete Primary School & 25.68 & 24.08 & 62.04 & 69.14 \\
\hline Complete Primary School & 9.47 & 7.74 & 11.67 & 9.48 \\
\hline Incomplete Secondary School & 23.86 & 21.66 & 11.01 & 7.41 \\
\hline Complete Secondary School & 25.14 & 24.78 & 2.04 & 1.38 \\
\hline Technician & 3.83 & 6.41 & 0.73 & 1.21 \\
\hline University Graduate & 0.36 & 2.74 & 1.71 & 0.52 \\
\hline Not sure/ No answer & 4.55 & 3.99 & 1.71 & 2.76 \\
\hline Total & 100.00 & 100.00 & 100.00 & 100.00 \\
\hline K-W p-value & \multicolumn{2}{|c|}{0.214} & \multicolumn{2}{|c|}{0.153} \\
\hline
\end{tabular}

Table 9 Family Members Years of Completed School (\%) 


\begin{tabular}{|c|c|c|}
\hline & \multicolumn{2}{|c|}{ Guatemala } \\
\hline & FT-Members & Non-Members \\
\hline $1-2$ years & 27.80 & 29.17 \\
\hline $3-4$ years & 24.97 & 29.17 \\
\hline $5-6$ years & 23.00 & 30.73 \\
\hline $7-8$ years & 6.77 & 1.56 \\
\hline $9-10$ years & 7.38 & 2.60 \\
\hline $11-12$ years & 8.36 & 3.39 \\
\hline $13-14$ years & 0.74 & 1.04 \\
\hline $15-16$ years & 0.49 & 0.52 \\
\hline $17-18$ years & 0.49 & 1.56 \\
\hline $19+$ years & & 0.26 \\
\hline Total & 100.00 & 100.00 \\
\hline Mean number of years & 5.49 & 4.95 \\
\hline Equal Mean T-test & & \\
\hline
\end{tabular}

Nicaraguan FT coop members tend to have a bit higher level of educational attainment than nonmembers. $\left(X^{2}=7.924 ; d f=1 ; p=0.005\right.$; Yates' Continuity Correction $\left.X^{2}=7.619 ; d f=1 ; p=0.006\right) . A$ higher proportion of children $10-15$ years old from the $F T$ coop members group are currently studying than from the non-members group. For these comparison groups, both non-parametric tests of median equality reject the equality of the medians.

In Peru, FT coop participation significantly and positively influences whether children are currently studying in the range of $10-11$ years old, negatively for those between 14 - 15 years of age, and positively for those between 20 and 21 years of age. Logit regressions suggest that youth, male gender, and other indicators of wealth are the primary factors affecting survey participants' educational attainments and aspirations. 
FT coop participation has some positive impact on school attendance among some categories of children and on some categories of educational aspiration.

Guatemalan FT coop members have completed an average of 5.49 years of school as opposed to 4.95 years of schooling among non-FT coop members. ( $t=-2.668$; $d f=781.168 ;$ two-tailed $\left.p=.008 ; K-W X^{2}=6.475 ; d f=1 ; p=.011\right)$. Sixty-three percent of Guatemalan FT coop member household members surveyed are currently in school compared to $50 \%$ of non-FT coop members surveyed $\left(K-W X^{2}=21.487 ; d f=1 ; p=.000\right.$; Median test $\left.X^{2}=21.503 ; d f=1 ; p=.000\right)$. Regarding educational aspiration, the modal or most frequent response among non-members of FT coops is that they desire household members to achieve a schooling level equivalent to incomplete primary school. The modal response among FT coop members is that they desire household members to complete secondary school $\left(\mathrm{K}-\mathrm{W} \mathrm{X}^{2}=22.75 ; \mathrm{df}=1 ; \mathrm{p}=.000\right)$.

\section{Health Indicators}

In Nicaragua, across illnesses such as colds and fevers or diarrhea, a higher percentage of ill children received medical treatment in the FT members group than in the non-members group. Other differences may not have been significant. However, we did find some significant differences in patterns of treatment seeking between FT coop members and non-members as shown in table 10. These comparisons are only between those afflicted; in many cases the rate of affliction is relatively low. Thus $25 \%$ of FT coop members and $34 \%$ of non FT members claim someone in the household suffered from malaria during the previous year.

Table 10. Patterns of Treatment Seeking for Illness in Nicaragua

\begin{tabular}{|l|l|c|}
\hline \multicolumn{1}{|c|}{ Illness } & \multicolumn{1}{c|}{$\begin{array}{c}\text { \% of afflicted Nicaraguans seeking } \\
\text { treatment }\end{array}$} & Significance tests \\
\hline $\begin{array}{l}\text { Dengue } \\
\text { Fever }\end{array}$ & $\begin{array}{l}88.2 \% \text { from the FT member group vs. } \\
43.8 \% \text { from the non-members group }\end{array}$ & $\mathrm{X}^{2}=64.103 ; \mathrm{df}=1 ; \mathrm{p}=0.000$ \\
\hline Diarrhea & 88.6 from the FT member group vs. & $\mathrm{X}^{2}=49.325 ; \mathrm{df}=1 ; \mathrm{p}=0.000$ \\
\hline
\end{tabular}




\begin{tabular}{|l|l|l|}
\hline & $55.4 \%$ from the non-members group & \\
\hline Malaria & $\begin{array}{l}81.4 \% \text { from the FT member group vs. } \\
52.4 \% \text { from the non-members group }\end{array}$ & $\mathrm{X}^{2}=32.341 ; \mathrm{df}=1 ; \mathrm{p}=0.000$ \\
\hline $\begin{array}{l}\text { Respiratory } \\
\text { Illness }\end{array}$ & $\begin{array}{l}\text { 83.7\% from the FT member group vs. } \\
49.3 \% \text { from the non-members group }\end{array}$ & $\mathrm{X}^{2}=103.229 ; \mathrm{df}=1 ; \mathrm{p}=0.000$ \\
\hline
\end{tabular}

In Peru, the comparison of the incidence of disease and patterns of treatment seeking are equivocal. A higher percentage of TF members than of non-members have received medical attention for colds and fevers. Some statistical tests suggest different patterns of illness between the two groups, with the FT coop participants suffering somewhat less.

In Guatemala, across all classes of illness FT coop members report lower incidents of disease in their households, and higher use of professional health services than non-FT coop members as suggested in Table 11.

Table 11. Patterns of Treatment Seeking for Illness in Guatemala

\begin{tabular}{|c|c|c|}
\hline Illness & $\%$ of Guatemalans seeking treatment & Significance tests \\
\hline Anemia & $\begin{array}{l}35.5 \% \text { of FT coop members vs. } 12.5 \\
\% \text { non-member }\end{array}$ & $\begin{array}{l}K-W X^{2}=1375.707 ; d f=1 ; \\
p=.000 ; \text { Median test } \\
X^{2}=1375.755 ; d f=1 ; p=.000\end{array}$ \\
\hline Colds and fevers & $\begin{array}{l}27.7 \% \text { of FT coop members vs. } 16.5 \\
\% \text { of non-members }\end{array}$ & $\begin{array}{l}K-W X^{2}=1416.18 ; d f=1 ; \\
p=.000 ; \text { Median test } \\
X^{2}=1416.192 ; d f=1 ; p=.000\end{array}$ \\
\hline Diarrhea & $\begin{array}{l}18.5 \% \text { of FT coop members vs. } 10 \% \\
\text { of non-members (Incidents reported } \\
\text { by } 75.2 \% \text { of non-FT member } \\
\text { households vs. } 35.2 \% \text { of FT coop } \\
\text { member households) }\end{array}$ & $\begin{array}{l}\mathrm{K}-\mathrm{W} \mathrm{X}^{2}=782.894 ; \mathrm{df}=1 ; \\
\mathrm{p}=.000 ; \text { Median test } \mathrm{X}^{2}= \\
782.902 ; \mathrm{df}=1 ; \mathrm{p}=.000\end{array}$ \\
\hline Malaria & $\begin{array}{l}35.2 \% \text { of FT members vs. } 30.2 \% \text { of } \\
\text { non-members (low overall incidence) }\end{array}$ & $\begin{array}{l}K-W X^{2}=13.393 ; d f=1 ; \\
p=.000 ; \text { Median test } \\
X^{2}=13.395 ; d f=1 ; p=.000\end{array}$ \\
\hline $\begin{array}{l}\text { Respiratory } \\
\text { infections }\end{array}$ & $\begin{array}{l}36.4 \% \text { of FT coop members vs. } \\
20.4 \% \text { of non-members }\end{array}$ & $\begin{array}{l}\text { K-W } X^{2}=1441.048 ; d f=1 ; \\
p=.000 ; \text { Median test } \\
X^{2}=1441.068 ; d f=1 ; p=.000\end{array}$ \\
\hline
\end{tabular}

\section{Development Opportunities}

Farmers generally report positive impacts of participation in Fair Trade coops on technical assistance across countries. FT coop members also report higher levels of 
social participation than non-members except in Peru where non FT participating respondents report they are active in local affairs. In no country do many nonparticipating farmers report receiving much technical or social assistance from local government services. In Guatemala and Nicaragua, cooperative members report receiving some support for health, education, and social programs from the cooperatives, while non-members report receiving lower levels of aid from local government as shown in tables 10 and 11. In Table 10, we report the number of responses above and below the median split. Those falling above the median are in the "no assistance" group; those below are in the "assistance received" group. In Peru, nonparticipants reported more local government support for social programs than did coop members.

Table 10. Receipt of Assistance in Technical and Social Programs: Nicaragua*

\begin{tabular}{|c|c|c|c|c|}
\hline Area of Support & & $\begin{array}{l}\text { FT Coop } \\
\text { Members }\end{array}$ & $\begin{array}{l}\text { Non- } \\
\text { Members }\end{array}$ & \\
\hline \multirow{2}{*}{$\begin{array}{l}\text { Social } \\
\text { Programs }\end{array}$} & $>$ Median & 84 & 83 & \multirow{2}{*}{$\begin{array}{l}\text { Median X2 =72.424; } \mathrm{df}=1 \\
\text { Asymp Sig. }=.000\end{array}$} \\
\hline & $<=$ Median & 247 & 37 & \\
\hline \multirow{2}{*}{$\begin{array}{l}\text { Technical } \\
\text { Assistance }\end{array}$} & $>$ Median & 27 & 106 & \multirow{2}{*}{$\begin{array}{l}\text { Median X2 =270.04; df=1; } \\
\text { Asymp Sig. }=.000\end{array}$} \\
\hline & $<=$ Median & 309 & 16 & \\
\hline \multirow{2}{*}{$\begin{array}{l}\text { Price } \\
\text { Negotiations }\end{array}$} & $>$ Median & 5 & 113 & \multirow{2}{*}{$\begin{array}{l}\text { Median X2 =399.695; } \\
\text { df=1; Asymp Sig. }=.000\end{array}$} \\
\hline & $<=$ Median & 331 & 6 & \\
\hline \multirow[t]{2}{*}{ Better housing } & $>$ Median & 96 & 113 & \multirow{2}{*}{$\begin{array}{l}\text { Median X2 =150.599; } \\
\text { df=1; Asymp Sig. }=.000\end{array}$} \\
\hline & $<=$ Median & 240 & 8 & \\
\hline
\end{tabular}

* Median split where 1=yes, 2=no;

Table 11. Receipt of Assistance in Technical and Social Programs: Guatemala

\begin{tabular}{|l|l|l|l|}
\hline & $\begin{array}{l}\text { FT Coop } \\
\text { Member }\end{array}$ & $\begin{array}{l}\text { Non- } \\
\text { Members }\end{array}$ & \\
\hline $\begin{array}{l}\text { Area of } \\
\text { Support }\end{array}$ & $\begin{array}{l}\text { Fair Trade } \\
\text { Coop }\end{array}$ & $\begin{array}{l}\text { Local } \\
\text { Government }\end{array}$ & Statistical Significance \\
\hline Education & $43.4 \%$ & $39.4 \%$ & $\mathrm{~K}-\mathrm{W} X^{2}=31.032 ; \mathrm{df}=1 ; \mathrm{p}=.000$ \\
\hline Health Care & $40 \%$ & $18 \%$ & $\mathrm{~K}-\mathrm{W} \mathrm{X}^{2}=1245.932 ; \mathrm{df}=1 ; \mathrm{p}=.000$ \\
\hline
\end{tabular}




\begin{tabular}{|l|r|r|l|}
\hline $\begin{array}{l}\text { Social } \\
\text { Programs }\end{array}$ & $27 \%$ & $18 \%$ & $\mathrm{~K}-\mathrm{W} \mathrm{X}^{2}=299.016 ; \mathrm{df}=1 ; \mathrm{p}=.000$ \\
\hline $\begin{array}{l}\text { Technical } \\
\text { Assistance }\end{array}$ & $80.7 \%$ & $5.8 \%$ & $\mathrm{~K}-\mathrm{W} \mathrm{X}^{2}=16671.416 ; \mathrm{df}=1 ; \mathrm{p}=.000$ \\
\hline $\begin{array}{l}\text { Price } \\
\text { Negotiations }\end{array}$ & $79.3 \%$ & $11.3 \%$ & $\mathrm{~K}-\mathrm{W} X^{2}=6591.239 ; \mathrm{df}=1 ; \mathrm{p}=.000$ \\
\hline
\end{tabular}

Although the data suggest that Fair Trade's support to cooperatives translates into positive attitudes toward cooperative intervention in social life, the impact of Fair Trade on perceived quality of life is more mixed. As show in Tables 12 and 13 in Nicaragua, FT coop members claim that both income and wellbeing have improved over the past three years. In Peru, FT participants claim that their overall welfare has not improved over the past three years, however non-FT participants indicate that their welfare has worsened. More FT participants than non-members also claim to be holding their own. Thus, at a minimum and consistent with the conservative nature of the sample drawn in Peru, FT participation may act as a kind of shock absorber, buffering members from other sources of stress in their lives. More than a quarter of Guatemalan FT coop members indicated that they were better off compared to their situation three years earlier, and less than one-fifth of non-members concurred with this assessment of wellbeing. Still 31\% of Guatemalan FT members said there situation had worsened compared to only $6 \%$ of non-members, while three quarters of non-participants detected no difference in their circumstances. The absence of dramatic improvements in perceived quality of life among FT members in Guatemala may be due to the combined effects on attitudes of a narrowing of price differences paid by Fair Trade and open market sources and the then recent devastation provoked by Hurricane Stan.

Table 12. Three-Year Trend in Well-being

\begin{tabular}{|l|l|l|}
\hline \multicolumn{3}{|c|}{ Nicaragua } \\
\hline FT Coop Members (\%) & Non-members (\%) & Significance Tests \\
\hline
\end{tabular}




\begin{tabular}{|c|c|c|c|c|c|c|}
\hline Better & Same & Worse & Better & Same & Worse & \\
\hline 77 & 20 & 3 & 41 & 30 & 29 & $\begin{array}{l}K-W X^{2}=64.6 ; d f=1 ; \\
p=.000\end{array}$ \\
\hline \multicolumn{7}{|c|}{ Peru } \\
\hline 14 & 47 & 39 & 6 & 36 & 58 & $\begin{array}{l}\text { Median } X^{2}=13.111 ; \\
d f=1 ; \\
P=.000\end{array}$ \\
\hline \multicolumn{7}{|c|}{ Guatemala } \\
\hline 27 & 41 & 31 & 16 & 76 & 6 & $\begin{array}{l}K-W X^{2}=180.059 ; d f= \\
1 ; p=.000\end{array}$ \\
\hline
\end{tabular}

Table 13. Three-Year Trend in Income

\begin{tabular}{|l|l|l|l|l|}
\hline \multicolumn{5}{|c|}{ Nicaragua } \\
\hline FT Coop Members (\%) & Non-Members (\%) & \\
\hline Higher & Lower & Higher & Lower & \\
\hline 62 & 11 & 45 & 25 & $\begin{array}{l}\text { K-W X } \\
\text { p. }=.013\end{array}$ \\
\hline \multicolumn{5}{|c|}{ Peru 163. df= 1, } \\
\hline 14 & 46 & 6 & 65 & $\begin{array}{l}\text { Median } \mathrm{X}^{2}=2.927 ; \mathrm{df}= \\
1 ; \mathrm{p}=.087 ; \text { not } \\
\text { significantly different }\end{array}$ \\
\hline 30 & \multicolumn{5}{|c|}{ Guatemala } & $\begin{array}{l}\mathrm{K}-\mathrm{W} \mathrm{X}^{2}=2294.235 ; \mathrm{df}= \\
1 ; \mathrm{p}=.000\end{array}$ \\
\hline
\end{tabular}

\section{Discussion}

In addition to a consistent pattern of results across countries, one thing inspires confidence in the data contained in the country reports, even if it suggests the wisdom of modesty in claims made about the local impacts of Fair Trade. This is that the data does not portray FT participation as a panacea or utopian solution to the problems of farming households in developing countries in Latin America. The impact results are more mixed than that. Across countries, there is no doubt that FT participating farmers are better paid for their coffee than non-participating farmers. But in Guatemala for example, some FT farmers claim that FT prices have stagnated relative to those paid by private buyers. In addition, not a few indicators of wellbeing are little different between FT and non-FT farmers. For example, very few people in our sample admitted to having 
any monetary savings of note or a bank account of any kind. And most people enjoyed limited access to health care even if FT participating farmers enjoyed a little more access than non-participating farmers. Thus, one can conclude that participation in Fair Trade is like a life jacket, a shock absorber, or a buffer against the effects of the volatility global market capitalism visits on the poor in developing countries. It is a safety net, but given current pricing levels, production regimes, and farm sizes, Fair Trade coffee alone is not THE solution to the problems of the rural poor.

The results of this study should be interpreted with some care. First, the stratification sampling procedure we used is appropriate for this type of impact assessment, especially since we had lists of all associated member producers in the countries studied. Thus, we were able to draw samples properly in advance of conducting field research. But the probability of inclusion of each observation collected varies depending on the actual procedures followed at each step of the sampling procedure. And it is very difficult to control the sampling procedures followed at the level of individual interviewers' choices made in the field. Thus, if our assumptions about the sampling procedures followed in each location and by each interviewer differ from the ones actually used, our results may be somewhat biased (no a-priori direction proposed).

Second, this is a cross-sectional study, meaning it is a snapshot frozen in time. As such it contains little meaningful trend data. In other words, informants' self-reports of trends should be treated as opinion data, rather than veridical claims about the direction of change in FT and non-FT affiliated communities. Trends can only be assessed by the comparison of data collected in this study with comparable data collected at later points in time and through similar means in the three countries.

Third, in general the results represent correlational measures rather than causal measures. In other words, if we state that FT farmers express greater optimism about 
the future than non-FT farmers we cannot conclude that FT membership causes greater optimism, only that greater optimism is associated with membership in FT coffee marketing schemes. The data do not allow us to exclude other possible reasons for this greater optimism; it may be that farmers with sunnier dispositions are disproportionately inclined to participate in FT schemes. Similarly, if we show that FT farmers enjoy greater access to electricity or piped water, we cannot conclude from this data that this was due to investments by FT coops or FT farmers themselves due to their higher incomes. They may have enjoyed better access prior to joining the FT movement, or local government may have provided these services for reasons unrelated to Fair Trade. That being said, a consistent pattern of favorable results does suggest that FT participation and wellbeing are somehow related and all things being equal, FT participation is generally in farmers' best interests.

A final limitation of this study is that it applies only to fairly-traded coffee and only to the Latin American experience, and only to fair-trade coffee sourced by Transfair, USA. We cannot extrapolate these results to other fairly traded agricultural commodities such as tea, sugar, and bananas, and we cannot extrapolate the results to experiences in Africa or South Asia, or to experiences of other Fair Trade organizations, for instance. By the same token, we have no reason to doubt the results would be similar in other Fair Trade market channels (see Parrish, Luzadis and Bentley 2005 on Tanzania and Raynolds, Murray and Taylor 2004 on El Salvador, Mexico and Guatemala, for example), but we have to refuse commentary about other situations elsewhere in the world.

In the aftermath of this descriptive study, future data collection should be structured around particular hypotheses to be tested. For example, if one was interested in producer incomes or in adherence to sustainable agricultural practices, then one could collect income and agricultural practice data and see how these were related to Fair 
Trade participation and data collected on the type of coffee produced, regime under which is grown (shaded area/non-shaded), fertilizer use, irrigation, highest level of education within the household, prices received, volume sold, etc.

Some specific lessons learned might guide future data collection as well. Our interviewers were somewhat opportunistic in their choice of who to interview within each household. We would recommend that interviews be taken only from the producer in charge of the family and in charge of the coffee production. One probably should not ask producers to comment retrospectively about average yields, volumes, prices, or income. Most people do not know how to assess an average measure. In the future, although quality of life measures are widely used, it might be advisable to avoid collecting data on producers' perceptions about their future, since this is such a subjective measure. Further, it might be advisable to reduce the number of questions about health status. For example, it might be better to ask how many family members have been sick with (list of diseases) during the last year? Ask if there was a need for medical attention? Ask, if they were able to obtain medical attention? And if not, ask for an explanation, for example, could not afford it, no physicians in the area, etc. Similar simplification to questions about education might also be proposed.

\section{Conclusion}

Results from a three-country survey of the effects of the market channel disintermediation, and the effort to transfer of value up the value chain to producers via price supports shows that producers participating in Transfair-supported Fair Trade cooperatives are indeed capturing more value than non-participants. These survey results are consistent with case study results reported from El Salvador, Guatemala, Mexico, Nicaragua, and Tanzania, (Bacon 2005; Parrish, Luzadis, and Bentley 2005; Raynolds, Murray and Taylor 2004; Taylor, Murray and Raynolds 2005). This benefit 
transfer translates into modest but measurable improvements in quality of life, health, education, material comforts, social participation, technical and social assistance, and even sustainable agricultural practices. This means that producers may be assured that participation in Fairtrade schemes is a good idea for them. It means that consumers who self-tax by paying higher retail prices in order to transfer value to producers, can have confidence that the scheme works as promoted. They are participating in a fairly represented ethical retailing program. Finally, it means that roasters, coffee houses and other retailers may be assured that they can defend the position that by agreeing to sell Fairtrade coffee they are participating in a social change campaign that delivers concrete benefits to small-scale producers in developing countries in Latin America as claimed.

\section{References}

Bacon, Christopher (2005), "Confronting the Coffee Crisis: Can Fair Trade, Organic, and Specialty Coffees Reduce Small-Scale Farmer Vulnerability in Northern Nicaragua?" World Development, 33 (March), 497-511.

Bird, K. and D.R. Hughes (1997), “Ethical Consumption: The Case of 'Fairly-Traded' Coffee," Business Ethics 6 (3), 159-167.

Crowell, Erbin (1997), "Notes from the Field: Building Fair Trade in Chiapas," Cultural Survival Quarterly 21 (2), 19-21.

Dickson, Marsha and Mary Littrell (1996), "Socially responsible behaviour: Values and Attitudes of the Alternative Trading Organization Consumer," Journal of Fashion Marketing and Management 1 (1), 50-69.

Grolleau, Gilles and Sandoss BenAbid (2001), "Fair Trading in Marketing for Credence Goods: An Analysis Applied to Agri-food Products," Intereconomics, 36 (July/August), 208-214. 
Johnston, J. (2002), "Consuming Social Justice: Fair Trade Shopping and Alternative Development," in J. Goodman (ed.) Protest and Globalisation, Pluto Press, Annandale, 38-56.

Littrell, Mary and Marsha Dickson (1998), "Fair Trade Performance in a Competitive Market," Clothing and Textiles Research Journal 16 (4), 176-189.

Marshland, Robert, de Vaal, Albert (2002), “How Fair is Fair Trade?” The Economist 150 (3), 251-272

Murray, Douglas, Laura T. Raynolds, and Peter Leigh Taylor (2003), One Cup at a Time: Poverty Alleviation and Fair Trade in Latin America, Ft Collins, CO: Colorado State University, CIESAS and Desarrollo Alternativo.

Nicholls, A. J. 2002. Strategic options for Fair Trade retailing. International Journal of Retail and Distribution Management 30(1):6-17.

MacDonald, G. Jeffrey (2006), "How to Brew Justice," Time, January 2006, A16-A17.

NCAUSA (2005), National Coffee Drinking Trends, 2005, NY: The National Coffee Association of USA, Inc.

Nicholls, Alex, and Charlotte Opal (2005) Fair Trade: Market Driven Ethical Consumption, London: Sage.

Parrish, Bradley D., Valerie A. Luzadis, and William R. Bentley (2005), “What Tanzania's Coffee Farmers Can Teach the World: A Performance Based Look at Fair TradeFree Trade Debate," Sustainable Development, 13, 177-189.

Raynolds, Laura T., Douglas Murray and Peter Leigh Taylor (2004), "Fair Trade Coffee: Building Producer Capacity via Global Networks," Journal of International Development, 16 1109-1121.

Ronchi, Loraine (2002), “The Impact of Fair Trade on Producers and Their Organisations: A Case Study With Cococafé in Costa Rica," Prus Working Paper No. 11, Brighton UK: University of Sussex. 
Strong, Carolyn (1997), "The Role of Fair Trade Principles within Sustainable Development," Sustainable Development 5 (1), 1-10.

Taylor, Peter Leigh Douglas Murray and Laura T. Raynolds (2005), "Keeping Fair Trade Fair: Governance Challenges in the Fair Trade Coffee Initiative," Sustainable Development, 13, 199-208.

The Economist (2006), "Fair Enough,” The Economist, April 1, 2006, p.33.

Welford, R., J. Meatonand and W. Young (2003), "Fair Trade as a Strategy for International Competitiveness," International Journal of Sustainable Development and World Ecology 10, 1-13.

Young, William and Richard Welford (2002), Ethical Shopping, London: Fusion Press. 